\title{
"ПОЛИТИЧЕСКИЙ АТЛАС СОВРЕМЕННОСТИ"
}

3 марта 2006 г. в МГИМО(У) МИД РФ состоялся методологический семинар, на котором были представлены предварительные результаты масштабного исследовательского проекта "Политический атлас современности" (научный руководитель - проф. А.Ю.Мельвиль), реализуемого учеными МГИМО(У) и Института общественного проектирования совместно с журналом "Эксперт". В рабочую группу проекта входят Т.А.Алексеева, О.В.Бутонина, М.В.Ильин, М.Г.Миронюк, Ю.А.Полунин, В.М.Сергеев И.Н.Тимофеев и др. В семинаре, проходившем под руководством чл.-корр. РАН, ректора МГИМО(У) А.В.Торкунова и директора Института общественного проектирования, главного редактора журнала “Эксперт” В.А.Фадеева, участвовали многие ведущие эксперты и аналитики, политологи, международники, представители политических партий и общественных движений.

В своем выступлении А.Ю.Мельвиль отметил, что главной научной целью проекта является развитие комплексных методов сравнительного анализа, оценки и мониторинга состояния и динамики политических систем и политических режимов в современном мире.

В современном мире - 191 суверенное государство. Все они члены ООН, но при этом находятся на разных ступенях развития; каждое из них уникально по своим политическим характеристикам и занимает особое место во взаимосвязанном глобальном сообществе. Чем на самом деле государства отличаются друг от друга? Насколько их способность обеспечи-

182 вать благополучие своих граждан зависит от типа политической системы, культурных традиций, экономических показателей, размера территории и других факторов? Можно ли эффективно сравнивать уникальные явления мировой политики? Как в сравнениях современных государств учесть особенности их истории и культуры, уровни развития и траектории эволюции? Разработать новые научно-методологические подходы к решению этих вопросов и призван проект “Политический атлас современности”.

Попытки сравнительного анализа и построения рейтингов стран по тем или иным критериям и параметрам предпринимаются давно. Уже в 1960-е годы начали создаваться базы данных и проводиться первые сравнения различных групп стран (К.Дойч, С.Роккан, С.Липсет, Р.Даль и др.). По мере совершенствования методологии сравнительного анализа интерес к компаративным исследованиям возрастал. Важный вклад в развитие этого направления внесли, в частности, Т.Ванханен, А.Лейпхарт, Т.Гурр, А.Картрайт и А.Инкелес. Проекты POLITY, инициированные Т.Гурром, дали важную концептуальную рамку и фактуру, по сей день не утратившие своего значения.

Однако политическая практика ставит все новые вопросы, и в поисках ответов на них политики и граждане нередко обращаются к более известным, но менее фундированным источникам - например, к рейтингам "Freedom House", "Transparency International", "Journalists Without Borders" и т.п. Между тем используемые этими центрами методики и шкалы оценки часто страдают фрагментарностью, субъективностью и односторонностью.

Проект "Политический атлас современности" предлагает модель многомерного сравнительного анализа политических систем и политических режи- 
мов, в основу которого положены не экспертные оценки (по определению субъективные), а строгие и верифицируемые статистические данные. Проект носит отчетливо междисциплинарный характер - в нем сочетаются политологические и точные количественные (математические) методы анализа.

Особенность данного проекта заключается в том, что “моментальная фотография" сегодняшних политических институтов и структур в нем дополнена анализом исторических, культурных и иных традиций, внутренних и внешних влияний и т.д. Выявляются индивидуальные особенности и специфические характеристики политических процессов в конкретных странах, темпы и фазы политических изменений и развития.

Проведенный анализ позволил построить интегрированную матрицу описания и сравнения политических систем и политических режимов современного мира, включающую свыше 150-ти “больших” (т.е. состоящих из разных компонентов) параметров. Выработаны шесть многомерных индексов национального и мирового развития: (1) индекс государственности; (2) индекс национальных угроз; (3) индекс внешнего влияния и включенности в мировые процессы; (4) индекс институциональной демократии; (5) индекс качества жизни, (6) индекс динамизма.

Математический анализ рейтингов подтвердил обоснованность и репрезентативность этих индексов и заложенных в них компонентов. Выявлены устойчивые корреляции между различными индексами. Например, индекс государственности положительно коррелирует с индексами качества жизни и динамизма и отрицательно - с индексом национальных угроз; индекс национальных угроз отрицательно коррелирует с индексами качества жизни и динамизма, а индексы институциональной демократии и внешнего влияния положительно коррелируют с индексом качества жизни.

Разумеется, не все страны следуют единой универсальной логике - анализ выявил и значительные “аномалии”. Национальное развитие осуществляется по многим параметрам в многомерном пространстве-времени. Нет заведомо “правильных" сочетаний факторов и приоритетов национального развития, равно как и абсолютно “дефектных” политических установок. Скорее можно говорить об исторически сложившемся своеобразии условий, приоритетов и установок, которое в значительной мере определяет возможности будущего развития каждой конкретной страны.

Что касается России, то она в чем-то воспроизводит общую для многих других стран логику, а в чем-то идет “своим путем”, отражающим особенности ее истории, культуры, а также задачи и приоритеты нынешнего этапа развития. Предварительный анализ показывает, что Россия остается одной из самых влиятельных стран мира с высокой степенью суверенности и среднеразвитыми формальными институтами демократии, но при этом сталкивается с очень серьезными угрозами и демонстрирует низкое качество жизни и слабый динамизм.

Важнейшая особенность “Политического атласа современности” заключается в том, что он представляет собой действующую и открытую аналитическую систему, которая в перспективе способна стать инструментом оценки конкретных международных и внутриполитических ситуаций, построения моделей разрешения конфликтов и разработки эффективных стратегий развития. 